Jurnal Ilmu Ilmu Agribisnis: Journal of Agribusiness Science, 9(4), Agustus 2021

\title{
KINERJA KOPERASI UNIT DESA (KUD) MINA DERMAGA KECAMATAN KALIANDA KABUPATEN LAMPUNG SELATAN BERDASARKAN PENDEKATAN TRIPARTITE
}

\author{
(Performance KUD Mina Dermaga in Kalianda, Lampung Selatan Based on Tripartite Approach)
}

Fadilla Sari, Dyah Aring Hepiana Lestari, Suriaty Situmorang

Jurusan Agribisnis, Fakultas Pertanian, Universitas Lampung, J1. Prof. Dr. Soemantri Brojonegoro No. 1

Bandar Lampung 35145,e-mail: dyah.aring@fp.unila.ac.id

\begin{abstract}
The purpose of this research is to analyze cooperative's performance as a business entity, performance related to development, performance towards the interests of cooperative members, as well as economic and non-economic benefits received by members. This research was conducted at KUD Mina Dermaga using a case study method, the location was selected purposively with the consideration that the cooperative has not yet been ranked by researchers or local agencies. Responses stating that 30 people members. This research uses descriptive quantitative data analysis, customer satisfaction index analysis, and importance performance analysis. The results of this study indicate that the performance of business entities and performance related to the development of KUD Mina Dermaga are included in the qualified category. The performance of KUD Mina Dermaga in the interests of its members is of sufficient quality category. The economic benefits received by members are the difference in the cost of buying and selling services. The total annual average economic benefits received by KUD Mina Dermaga members are IDR 508,358.26. The non-economic benefits members on service performance and meeting the needs of members are in the high category (satisfied).
\end{abstract}

Keyword: KUD, member satisfaction, performance

Received: 22 December $2020 \quad$ Revised: 11 January 2021

\section{PENDAHULUAN}

Indonesia memiliki tiga sektor penting dalam perekonomian, yaitu negara, swasta dan koperasi. Sebagai salah satu sektor penting dalam perekonomian, koperasi memiliki kedudukan khusus, koperasi diharapkan dapat menjadi tiang utama dalam perekonomian. Perkoperasian Indonesia dinilai memiliki kontribusi cukup penting, yaitu menciptakan nilai tambah, lapangan pekerjaan, dan meningkatkan perekonomian daerah.

Provinsi Lampung merupakan provinsi yang memiliki jumlah koperasi yang cukup banyak dan mengedepankan koperasi sebagai pelaku penting dalam perekonomian namun masih banyak koperasi yang berstatus pasif. Menurut Dinas Koperasi dan UKM (2018), Provinsi Lampung memiliki 5.414 unit koperasi, dan hanya 41,94 persen yang aktif dan sisanya tergolong koperasi pasif. Salah satu koperasi yang masih aktif dalam aktivitas usahanya adalah Koperasi Unit Desa (KUD) Mina Dermaga yang berlokasi di Kecamatan Kalianda Kabupaten Lampung Selatan koperasi ini diresmikan sejak Mei 2011
Accepted:27 January $2021 \quad$ DOI: http://dx.doi.org/10.23960/jiia.v9i4.5402

Koperasi merupakan salah satu organisasi ekonomi yang harus menjaga keberlangsungan kegiatan usahanya didukung dengan pelaksanaan manajemen yang baik, sehingga akan mempengaruhi kinerja koperasi. Sejak diresmikan KUD Mina Dermaga belum pernah dinilai kinerjanya. Menurut Hanel (2005), peniliaian kinerja koperasi dapat dilakukan dengan tiga pendekatan (tripartite), yaitu kinerja sebagai badan usaha, kontribusi terhadap pembangunan dan keberhasilan dalam memberikan manfaat kepada anggota.

Berdasarkan uraian sebelumnya, maka tujuan penelitian ini adalah menganalisis kinerja KUD Mina Dermaga sebagai badan usaha, kontribusi terhadap pembangunan, serta manfaat ekonomi dan non ekonomi (kepuasan) yang diterima oleh anggota KUD Mina Dermaga.

\section{METODE PENELITIAN}

Metode yang digunakan pada penelitian ini adalah metode studi kasus. Lokasi penelitian ditentukan secara sengaja (purposive) dengan pertimbangan bahwa KUD Mina Dermaga merupakan koperasi perikanan aktif yang sampai saat ini belum pernah 
dinilai kinerjanya. Pengambilan data dilakukan pada bulan Juni 2020-Juli 2020.

KUD Mina Dermaga memiliki anggota berjumlah 300 orang, akan tetapi hanya 150 orang yang tergolong anggota aktif. Penelitian ini mengambil sampel sebanyak 20 persen dari anggota aktif maka didapat jumlah sampel sebanyak 30 orang. Data yang digunakan pada penelitian ini adalah data primer dan data sekunder. Data primer didapat langsung dengan melakukan wawancara pengurus, dan anggota KUD Mina Dermaga dengan menggunakan daftar pertanyaan (kuesioner). Data sekunder didapat dari data-data pembukuan KUD Mina Dermaga serta dinas atau instasi terkait.

Metode yang digunakan untuk menganalisis kinerja koperasi menggunakan Peraturan Menteri Negara Koperasi dan Usaha Kecil dan Menengah Republik Indonesia Nomor 21/Per/M.KUKM/IX/2015 tentang Pedoman Pemeringkatan Koperasi. Terdapat 5 (lima) aspek. Kinerja KUD Mina Dermaga sebagai badan usaha diukur menggukanan tiga aspek, yaitu aspek kelembagaan, aspek usaha dan aspek keuangan. Kinerja yang berkaitan dengan pembangunan diukur menggunkan aspek manfaat koperasi terhadap masyarakat dan kinerja terhadap kepentingan anggota diukur menggunakan aspek manfaat koperasi terhadap anggota.

Kinerja koperasi sebagai badan usaha memiliki 25 indikator penilaian dengan nilai parameter berkisar 0-500 dan bobot yang berbeda disetiap aspek penilaian. Kinerja koperasi yang berkaitan dengan pembangunan memiliki tiga indikator penilaian dengan nilai parameter 0-200. Kinerja koperasi terhadap kepentingan anggota memiliki lima indikator penilaian dengan nilai parameter berkisar 0-200.

Metode analisis yang digunakan untuk menjawab tujuan manfaat ekonomi dan non ekonomi anggota koperasi adalah deskriptif kuantitatif. Manfaat ekonomi koperasi terbagi menjadi dua, yaitu manfaat ekonomi tunai dan manfaat ekonomi yang diperhitungkan (Sudarsono, 2005). Kepuasan anggota koperasi dianalisis menggunakan metode Customer Statisfaction Index (CSI) dan Importance Performance Analysis (IPA). Hasil penilaian CSI dibagi menjadi lima, nilai 0 persen 34 persen artinya tidak puas, nilai 35 persen - 50 persen kurang puas, nilai 51 persen -65 persen cukup puas, nilai CSI 66 persen -80 persen puas, nilai 81 persen - 100 persen sangat puas (Supranto, 2003). Metode IPA digunakan untuk melihat atribut-atribut yang mempengaruhi kepuasan anggota koperasi. Hasil penilaian IPA terbagi menjadi empat kuadran, yaitu prioritas utama (kuadran I), pertahankan prestasi (kuadran II), prioritas rendah (kuadran III), berlebihan (IV).

Sebelum dilakukan analisis kepuasan anggota koperasi, terlebih dahulu dilakukan uji validitas dan uji reliabilitas terhadap kuesioner. Kuesioner dikatakan valid apabila corrected item bernilai $>0,2$ dan dikatakan reliabel apabila cronbach's alpha bernilai $>0,6$. Hasil seluruh butir pertanyaan sudah valid dan reliabel dengan nilai corrected item >0,2 dan cronbach's alpha >0,6 artinya kuesioner siap digunakan.

\section{HASIL DAN PEMBAHASAN}

KUD Mina Dermaga merupakan koperasi yang didirikan dari gabungan kelompok nelayan di wilayah Kalianda, dengan kantor sekretariat yang terletak di Dermaga Pantai Boom Kecamatan Kalianda. Tanggal 12 Mei 2011 koperasi ini resmi menjadi lembaga formal dengan nomor akta pendirian 07/BH/X.I/III.07.2011. Saat ini KUD Mina Dermaga menjalankan lima unit usaha, yaitu simpan pinjam, pelelangan ikan, penyedia bahan bakar, penyedia air bersih, dan bangunan kuliner. Koperasi ini mengalami pembaruan akta pendirian pada tanggal 31 Maret 2016 dengan nomor akta, yaitu 99/BH/PAP/X.1/III.09/III/2016.

\section{Karakteristik Responden}

Responden yang digunakan pada penelitian ini adalah pengurus dan anggota KUD Mina Dermaga. Pengurus KUD Mina Dermaga berumur variatif di antaranya 46-53 tahun, dengan tingkat pendidikan seluruhnya adalah Sekolah Menengah Atas (SMA). Pengurus koperasi terdiri atas ketua, wakil ketua, sekretaris, wakil sekretaris dan bendahara. Anggota KUD Mina Dermaga memberikan informasi mengenai kepuasan terhadap pelayanan dan terpenuhinya kebutuhan anggota. Umur anggota berkisar antar 30-60 tahun. Tingkat pendidikan anggota koperasi sebagian besar berada di SMP dan SMA. Jumlah tanggungan anggota rumah tangga antara 2-7 orang dengan pengalaman berkoperasi selama 2-8 tahun. 
Tabel 1. Sebaran hasil penilaian kinerja KUD Mina Dermaga sebagai badan usaha, 2020

\begin{tabular}{|c|c|c|c|}
\hline No & Aspek dan Indikator & Nilai Maksimal & Nilai diperoleh \\
\hline \multicolumn{4}{|c|}{ Kinerja sebagai Badan Usaha } \\
\hline & A. Aspek Kelembagaan Koperasi (30\%) & & \\
\hline 1. & Legalitas badan hukum & 500 & 300 \\
\hline 2. & Partisipasi anggota dalam permodalan & 200 & 200 \\
\hline 3. & Alat kelengkapan organisasi & 200 & 200 \\
\hline 4. & Rencana strategi (renstra) & 200 & 100 \\
\hline 5. & Standar operasional prosedur (SOP) & 300 & 100 \\
\hline 6. & Standar operasional manajemen (SOM) & 300 & 200 \\
\hline 7. & Rapat anggota & 400 & 200 \\
\hline 8. & Pendidikan dan pelatihan & 400 & 100 \\
\hline 9. & Rasio peningkatan jumlah anggota & 200 & 200 \\
\hline 10. & Penghargaan koperasi 3 tahun terakhir & 200 & 0 \\
\hline \multicolumn{4}{|c|}{ B. Aspek Usaha Koperasi (25\%) } \\
\hline 11. & Legalitas usaha & 100 & 100 \\
\hline 12. & Keterikatan aktivitas usaha anggota dengan usaha anggota lain & 100 & 100 \\
\hline 13. & Keterikatan aktivitas usaha anggota dengan usaha koperasi & 100 & 100 \\
\hline 14. & Peningkatan volume usaha & 100 & 0 \\
\hline 15 & Peningkatan kapasitas produksi jasa & 100 & 100 \\
\hline 16. & Peningkatan SHU & 100 & 0 \\
\hline \multicolumn{4}{|c|}{ C. Aspek Keuangan Koperasi (30\%) } \\
\hline 17. & Struktur permodalan koperasi & 100 & 50 \\
\hline 18. & Tingkat likuiditas & 300 & 150 \\
\hline 19 & Persentase pelunasan simpanan wajib anggota & 100 & 0 \\
\hline 20. & Total kewajiban jangka pendek terhadap aset & 200 & 200 \\
\hline 21. & Kemampuan koperasi untuk melunasi kewajiban & 100 & 100 \\
\hline 22. & Rasio laba bersih terhadap aset investasi (ROI) & 100 & 0 \\
\hline 23. & Penambahan aset & 100 & 100 \\
\hline 24. & Audit kantor akuntan publik (KAP) & 200 & 75 \\
\hline 25. & Keberlanjutan usaha & 200 & 50 \\
\hline
\end{tabular}

Sumber : Pedoman Pemeringkatan Koperasi, 2015

\section{Aspek Kelembagaan Koperasi}

Aspek kelembagaan diukur dengan beberapa indikator, yaitu legalitas badan hukum belum diberikan nilai maksimal karena pendirian KUD Mina Dermaga belum diumumkan dan ditambahkan dalam berita Negara Republik Indonesia (RI). Indikator rencana strategi (renstra) dan standar operasional manajemen (SOM) belum diberikan nilai maksimal, karena koperasi belum memiliki RAPBK dan belum memiliki aturan terkait pengambilan keputusan. Selanjutnya indikator rapat anggota belum diberikan nilai maksimal karena saat ini yang menjadi pimpinan sidang dalam pembahasan pertanggung jawaban adalah pengurus koperasi, anggota tidak berpartisipasi menjadi pimpinan sidang oleh karena itu belum diberikan nilai maksimal.

Aspek kelembagaan memiliki beberpa indikator yang perlu diperbaiki, yaitu standar operasional prosedur (SOP), pendidikan dan pelatihan, serta penghargaan koperasi tiga tahun terakhir. KUD Mina Dermaga belum memiliki peraturan sah yang tertulis dalam AD/ART mengenai SOP usaha dan
SOP keuangan sampai saat ini pengurus koperasi hanya mengandalkan pengalaman dalam menjalankan usahanya. KUD Mina Dermaga sampai saat ini belum mengadakan pendidikan dan pelatihan kerena membutuhkan biaya yang cukup besar. Selama tiga tahun terakhir KUD Mina Dermaga belum pernah menerima penghargaan dari dalam maupun luar Kementerian Koperasi sebaiknya pengurus meningkatkan kinerja dan kualitas agar koperasi dapat meraih penghargaan.

Indikator yang telah dijalankan dengan baik, yaitu partisipasi anggota dalam permodalan dan alat kelengkapan koperasi. Persentase pelunasan simpanan wajib sebesar 50,33 persen dan persentase anggota yang aktif bertransaksi sebesar 53,67 persen. Alat kelengkapan organisasi KUD Mina Dermaga dinilai sudah lengkap, karena terdapat struktur organisasi dan pembagian tugas telah sesuai dengan yang tertulis dalam $\mathrm{AD} / \mathrm{ART}$ koperasi. Secara keseluruhan penilaian aspek kelembagaan mendapatkan nilai 1.600 dari nilai maksimal 2.900, dan aspek ini memiliki bobot nilai 30 persen. 


\section{Aspek Usaha Koperasi}

Aspek usaha koperasi terdiri atas enam indikator, yaitu legalitas usaha, keterkaitan aktivitas usaha anggota dengan anggota lain, keterkaitan usaha anggota dengan usaha koperasi, peningkatan volume usaha, peningkatan kapasitas produksi/jasa, peningkatan SHU. Hasil penilaian aspek usaha, yaitu 400 dari nilai maksimal 600 dengan bobot nilai 25,00 persen.

Indikator yang perlu diperbaiki adalah peningkatan volume usaha dan peningkatan SHU. KUD Mina Dermaga mengalami penurunan omset sebesar 25,87 persen, pada akhir tahun 2018 terjadi bencana tsunami yang mengakibatkan kerugian yang cukup besar serta kerusakan dan penurunan pendapatan dari setiap unit usaha koperasi. Persentase SHU tahun 2019 mengalami penurunan sebesar 17,03 persen, hal ini terjadi karena penurunan pendapatan. KUD Mina Dermaga harus meningkatkan pendapatannya sehingga mampu membagikan SHU kepada setiap anggotanya.

Indikator lainnya telah dijalankan dengan baik, koperasi telah memiliki kesesuaian izin usaha yang dilengkapi dengan surat izin berupa nomor pokok wajib pajak (NPWP), surat izin usaha perdagangan (SIUP), tanda daftar perusahan (TDP), surat izin tempat usaha (SITU), surat izin gangguan usaha (HO) dan lainya. Semua unit usaha yang terdapat di KUD Mina Dermaga didirikan berdasarkan kebutuhan anggota dan persentase peningkatan kapasitas produk dan jasa pada tahun 2019 sebesar 25,74 persen, karena penambahan beberapa unit usaha pada koperasi.

\section{Aspek Keuangan Koperasi}

Aspek keuangan koperasi memiliki beberapa indikator, yaitu struktur permodalan yang berasal dari modal sendiri dan modal pinjaman dari lembaga keuangan. Indikator tingkat likuiditas terdiri dari tiga parameter, hasil perhitungan cash ratio KUD Mina Dermaga adalah 1,44 persen, acid test ratio dan current ratio memiliki hasil yang sama, yaitu 95,73 persen.

Pada aspek keuangan koperasi ada beberapa indikator yang perlu diperbaiki, yaitu pelunasan simpanan wajib, rasio laba bersih terhadap investasi. Indikator persentase pelunasan simpanan wajib mengalami penurunan sebesar 17,54 persen karena banyak anggota yang tidak membayar simpanan wajib.
Tabel 2. Hasil penilaian kinerja KUD Mina Dermaga sebagai badan usaha, 2020

\begin{tabular}{|c|c|c|c|c|}
\hline Indikator & $\begin{array}{l}\text { Nilai } \\
\text { Maks }\end{array}$ & $\begin{array}{c}\text { Nilai } \\
\text { diperoleh }\end{array}$ & $\begin{array}{c}\text { Bobot } \\
(\%)\end{array}$ & Hasil \\
\hline $\begin{array}{l}\text { 1. Aspek } \\
\text { kelembagaan }\end{array}$ & 2.900 & 1.600 & 30 & 480 \\
\hline 2. Aspek usaha & 600 & 300 & 25 & 75 \\
\hline $\begin{array}{l}\text { 3. Aspek } \\
\text { keuangan }\end{array}$ & 1.300 & 725 & 25 & 181,25 \\
\hline Total & & & & 761,25 \\
\hline Kategori & & & \multicolumn{2}{|c|}{ Berkualitas } \\
\hline
\end{tabular}

Hasil perhitungan mendapatkan Rasio laba bersih terhadap investasi (ROI) diperoleh rasio sebesar 0,08 persen artinya setiap $\mathrm{Rp} 1,00$ aset yang dimiliki koperasi dapat menghasilkan laba bersih sebesar Rp0,08 persentase ROI tergolong rendah. Indikator yang telah dijalankan dengan baik, yaitu persantase kewajiban jangka pendek terhadap aset diperoleh rasio sebesar 1,1 persen dan dinilai sudah efektif. Indikator kemampuan koperasi dalam memenuhi kewajiban (solvabilitas) adalah sebesar 431,00 persen yang artinya sebesar Rp1,00 hutang koperasi dapat dijamin dengan Rp431,00 dari total aktiva koperasi. Hasil penilaian kinerja KUD Mina Dermaga sebagai badan usaha dengan nilai 761,25 termasuk dalam kategori berkualitas (6801019).

\section{Kinerja KUD Mina Dermaga yang Berkaitan dengan Pembangunan}

Kinerja KUD Mina Dermaga yang berkaitan dengan pembangunan dinilai dengan aspek manfaat koperasi bagi masyarakat yang terdapat beberapa indikator, yaitu penyerapan tenaga kerja, jumlah layanan koperasi yang dapat dinikmati dan penurunan tingkat kemiskinan. Indikator jumlah layanan koperasi yang dapat dinikmati masyarakat dinilai baik, hal ini karena KUD Mina Dermaga memberikan dampak bagi masyarakat dibidang sosial, dengan memberikan bantuan kepada anggota yang terkena musibah dan pengadaan air bersih.

KUD Mina Dermaga juga telah berkontribusi dalam penyerapan tenaga kerja dengan jumlah tenaga kerja sebanyak 19 orang yang terbagi disetiap unit usaha koperasi dengan tanggung jawab yang berbeda. Indikator penurunan tingkat kemiskinan harus diperbaiki, karena KUD Mina Dermaga belum memiliki anggaran dana khusus yang digunakan sebagai bentuk tanggung jawab koperasi terhadap lingkungannya. 
Berdasarkan uraian sebelumnya, didapatkan nilai keseluruhan sebesar 225 dari nilai maksimal 400. Bobot penilaian aspek ini sebesar 10 persen, hasil penilaian yang didapat adalah 22,50 masuk dalam kategori berkualitas. Hasil penelitian ini berbeda dengan penelitian Sormin, Lestari dan Situmorang (2019), yang menyebutkan bahwa hasil penilaian kinerja KPT Maju Sejahtera yang berkaitan dengan pembangunan masuk dalam kategori cukup berkualitas dengan nilai yang peroleh adalah 15,00.

\section{Kinerja KUD Mina Dermaga terhadap Kepentingan Anggota}

Penilaian kinerja KUD Mina Dermaga terhdap kepentingan anggota berkaitan dengan aspek manfaat koperasi bagi anggota. Pada penilaian ini terdapat beberapa indikator yang perlu diperbaiki, yaitu peningkatan penghasilan anggota yang berkaitan dengan SHU yang diterima dan jumlah anggota yang usahanya naik kelas.

KUD Mina Dermaga belum bisa membagikan SHU kepada anggota, karena pada tahun 2018 mengalami kerugian cukup besar (hampir koleps) dan pengurus koperasi meminjam modal yang besar kepada lembaga keuangan.

Indikator yang telah dijalankan dengan baik, yaitu harga barang dan jasa lebih rendah dan pemberian pelayanan koperasi diluar aktivitas usaha. Harga barang atau jasa yang ditawarkan kepada anggota koperasi lebih rendah dari harga pesaing, rincian harga dapat dilihat pada Tabel 3.. KUD Mina Dermaga telah memberikan pelayanan diluar aktivitas usaha koperasi, yaitu dibidang sosial dengan memberikan bantuan jika anggota koperasi terkena musibah.

Berdasarkan uraian sebelumnya, hasil penilaian KUD Mina Dermaga terhadap kepentingan anggota mendapatkan nilai 350 dari nilai maksimal 400. Aspek ini memiliki bobot nilai 10,00 persen jadi hasil akhir penilaian adalah 35 dan masuk dalam kategori cukup berkualitas. Penelitian ini sejalan dengan penelitian Sormin, Lestari dan Situmorang (2019), yang menyebutkan bahwa kinerja KPT Maju Sejahtera terhadap kepentingan anggota juga masuk dalam kategori cukup berkualitas.

\section{Manfaat Ekonomi yang Diterima Anggota}

Manfaat ekonomi yang diterima anggota KUD Mina Dermaga terbagi menjadi dua, yaitu manfaat ekonomi tunai dan manfaat ekonomi yang diperhitungkan. Manfaat ekonomi tunai yang diterima oleh anggota berupa sisa hasil usaha (SHU) dan tunjangan. Manfaat ekonomi yang diperhitungkan berupa harga pelayanan. Anggota KUD Mina Dermaga belum menerima SHU dan tunjangan selama dua tahun terakhir, hal ini terjadi karena pada awal tahun 2018 KUD Mina Dermaga mengalami keterpurukan (hampir koleps) di setiap unit usahanya kemudian pengurus koperasi mengajukan pinjaman modal yang cukup besar kepada lembaga keuangan untuk memperbaiki kegiatan usahanya. Saat ini SHU belum dibagikan kepada anggota koperasi dan masih digunakan untuk perputaran modal serta pengembalian pinjaman modal kepada lembaga keuangan.

Manfaat ekonomi yang diperhitungkan terdiri dari harga pelayanan dari setiap unit usaha koperasi. harga pelayanan merupakan selisih harga di koperasi dan di luar koperasi atau harga pesaing. Anggota KUD Mina Dermaga menerima beberapa manfaat ekonomi yang diperhitungkan, yaitu selisih harga pembelian, selisih harga penjualan, selisih harga sewa, dan selisih bunga kredit. Ratarata manfaat ekonomi yang diterima anggota KUD Mina Dermaga dapat dilihat pada Tabel 4.

Data pada Tabel 4, unit usaha yang memperoleh rata-rata nilai manfaat ekonomi tertinggi adalah harga pelayanan dari penjualan TPI, yaitu sebesar Rp279.754,10 per tahun. Rata-rata manfaat ekonomi yang diterima oleh anggota per tahun sebesar Rp508.385,24. Hasil penelitian ini sejalan dengan penelitian Wiandhani, Lestari, dan Soelaiman (2015) memperoleh manfaat ekonomi sebesar Rp400.490,00 per tahun artinya KUD Mina Dermaga memberikan maanfaat ekonomi yang diterima anggota lebih besar dari penelitian tersebut karena memiliki lebih banyak unit usaha.

Tabel 3. Harga barang atau jasa pada KUD Mina Dermaga, 2020

\begin{tabular}{|c|c|c|c|c|}
\hline Nama Produk & $\begin{array}{l}\text { Harga di } \\
\text { koperasi }\end{array}$ & $\begin{array}{l}\text { Harga } \\
\text { diluar } \\
\text { Kop }\end{array}$ & Selisih & $\%$ \\
\hline $\begin{array}{l}\text { 1.Pembelian ikan } \\
\text { tangkap (Rp/Kg) }\end{array}$ & 25.000 & 27.750 & 2.750 & 9,91 \\
\hline $\begin{array}{l}\text { 2.Pembelian air } \\
\text { bersih }(\mathrm{Rp} / \mathrm{L})\end{array}$ & 100 & 150 & 50 & 33,33 \\
\hline $\begin{array}{l}\text { 3.Pembelian solar } \\
(\mathrm{Rp} / \mathrm{L})\end{array}$ & 5.150 & 6.250 & 1.100 & 17,60 \\
\hline $\begin{array}{l}\text { 4. Sewa gedung } \\
\text { kuliner (Rp/bulan) }\end{array}$ & 100.000 & 150.000 & 50.000 & 33,33 \\
\hline $\begin{array}{l}\text { 5.Simpan pinjam } \\
(\%)\end{array}$ & 0,07 & 0,165 & 0,095 & 57,57 \\
\hline
\end{tabular}


Tabel 4. Rata-rata manfaat ekonomi yang diterima oleh anggota KUD Mina Dermaga, 2020

\begin{tabular}{lr}
\hline Manfaat Ekonomi Kopersi & Jumlah (Rp/th) \\
\hline Tunai & 0 \\
SHU & 0 \\
Tunjangan & 0 \\
\hline Total MEK Tunai (Rp/th) & \\
\hline Diperhitungkan & \\
Harga pelayanan dari pembelian & $83.770,49$ \\
a. TPI & $52.475,41$ \\
b. SPBN & $14.221,31$ \\
c. Air bersih & \\
Harga pelayanan penjualan & $279.754,10$ \\
a. TPI & $72.426,23$ \\
Harga pelayanan pinjaman & \\
a. Simpan pinjam & $5.737,70$ \\
Harga pelayanan sewa & $508.385,24$ \\
a. Bangunan kuliner & $508.385,24$ \\
\hline Total MEK diperhitungkan (Rp/th) \\
\hline Total MEK
\end{tabular}

\section{Manfaat Nonekonomi}

Manfaat nonekonomi yang dirasakan oleh anggota KUD Mina Dermaga dapat diukur berdasarkan kepuasan anggota terhadap kualitas pelayanan dan kepuasan terpenuhinya kebutuhan anggota. Penelitian ini mengukur manfaat nonekonomi (kepuasan) terhadap anggota koperasi.

Sebelum dilakukan pengambilan data, dilakukan uji validitas dan uji reliabilitas dengan menggunakan 30 orang responden dan mendapatkan hasil, yaitu semua item pertanyaan yang akan digunakan reliable dan valid. Hal ini menunjukan bahwa pertanyaan dapat digunakan untuk pengambilan data penelitian. Analisis kepuasan anggota koperasi dilakukan dengan menggunakan dua metode, yaitu Customer Satisfaction Index (CSI) dan Importance Performance Analysis (IPA).

\section{Customer Statisfaction Index (CSI)}

Analisis CSI mengaitkan antara atribut yang diharapkan yaitu harapan anggota terhadap kinerja koperasi dan atribut yang dirasakan oleh anggota. Menurut A.H. Maslow dalam Hasibuan (2011) kepuasan pelayanan diukur menggunakan lima aspek, yaitu kebutuhan fisik, kebutuhan rasa aman dan keselamatan, kebutuhan sosial, kebutuhan penghargaan diri dan kebutuhan aktualisasi diri. Analisis CSI yang diukur dengan rumus:

$\mathrm{CSI}=\mathrm{T} / 5 \mathrm{Y}$
Tabel 5. Hasil penilaian tingkat kepuasan anggota KUD Mina Dermaga, 2020

\begin{tabular}{|c|c|c|c|}
\hline Indikator kepuasan & $\begin{array}{c}\text { Total } \\
\text { nilai }(\mathrm{Y})\end{array}$ & $\begin{array}{c}\text { Total } \\
\text { skor }(\mathrm{T})\end{array}$ & $\begin{array}{c}\text { Nilai } \\
\text { CSI }(\%)\end{array}$ \\
\hline 1. Kualitas pelayanan & 148,37 & 532,34 & 71,75 \\
\hline $\begin{array}{l}\text { 2. Terpenuhinya } \\
\text { kebutuhan anggota }\end{array}$ & 95,34 & 327,47 & 68,70 \\
\hline
\end{tabular}

Hasil perhitungan kepuasan anggota KUD Mina Dermaga dapat dilihat pada Tabel 5. Kepuasan anggota koperasi menunjukan bahwa nilai CSI yang didapat dari kepuasan anggota terhadap kualitas pelayanan sebesar 71,75 persen dan kepuasan anggota terhadap terpenuhinya kebutuhan sebesar 68,70 persen. Hal ini menunjukan bahwa anggota KUD Mina Dermaga puas akan pelayanan yang diberikan koperasi dan terpenuhinya kebutuhan anggota koperasi.

Penelitian ini sejalan dengan penelitian yang dilakukan oleh Saputri, Lestari, dan Sayekti (2019) hasil penelitian menyatakan bahwa hasil penilaian CSI kepuasan anggota koperasi terhadap pelayanan sebesar 70,57 persen dan kepuasan terhadap terpenuhinya kebutuhan anggota sebesar 74,39 persen. Hal ini menunjukan bahwa anggota merasa puas terhadap kinerja koperasi.

\section{Importance Performance Analysis (IPA)}

Hasil IPA tingkat kepuasan anggota KUD Mina Dermaga dapat dilihat pada Gambar 1 dan 2, menunjukan hasil pemetaan dari atribut-atribut perbandingan rata-rata tingkat kinerja dengan kepentingan. Aspek pada kuadran I menunjukan bahwa aspek tersebut dinilai penting namun kinerja koperasi belum sesuai dengan yang diharapkan anggota. Aspek yang terdapat pada kuadran I adalah perhatian petugas dalam melayani dan kemampuan dalam memberikan informasi.

Aspek pada kuadran I harus diperhatikan dan ditingkatkan karena memiliki pengaruh yang besar terhadap kepuasan anggota koperasi. Kuadran II menunjukan bahwa aspek tersebut dianggap penting oleh anggota dan kinerja koperasi pun sudah baik. Berdasarkan hasil pemetaan diagram IPA terdapat lima aspek yang masuk dalam kuadran II yaitu, kesopanan dalam pelayanan, kebutuhan pangan, kebutuhan sandang kebutuhan akan perasaan diterima dan kebutuhan akan perasaan dihormati. 
Tabel 6. Hasil keseluruhan IPA tingkat kepuasan anggota KUD Mina Dermaga, 2020

\begin{tabular}{lcccc}
\hline Indikator & \multicolumn{4}{c}{ Kuadran } \\
\cline { 2 - 5 } kepuasan & I & II & III & IV \\
\hline Kualitas & E1, & A1 & A2, & E2, \\
pelayanan & S2 & & R2, & R1, \\
koperasi & & & R3, S1 & T1, \\
& & & & T2, T3 \\
\hline Terpenuhinya & - & P1, P2, & P3, P4, & P11 \\
kebutuhan & & P7, P9 & P5, P6, \\
anggota & & & P8, \\
& & & P10 \\
\hline
\end{tabular}

Aspek yang terdapat pada kuadran III menunjukan bahwa aspek-aspek tersebut tidak terlalu dianggap penting oleh anggota dan penilaian kinerja koperasi pun tidak terlalu baik. Aspek tersebut memiliki prioritas rendah dalam perbaikanya yang artinya dalam peningkatan pada aspek-aspek dalam kuadran III ini sangat perlu dipertimbangkan karena, aspek tersebut memiliki pengaruh kecil terhadap kepuasan yang diterima oleh anggota koperasi. . Aspek yang terdapat pada kuadran IV dinilai berlebihan, yaitu penilaian aspek-aspek tersebut dianggap kurang terlalu penting oleh anggota namun kinerja koperasi sudah sangat baik. Peningkatan aspek-aspek pada kuadran III dan IV dapat diperbaiki jika aspek pada kuadran I (prioritas utama) telah diperbaiki.

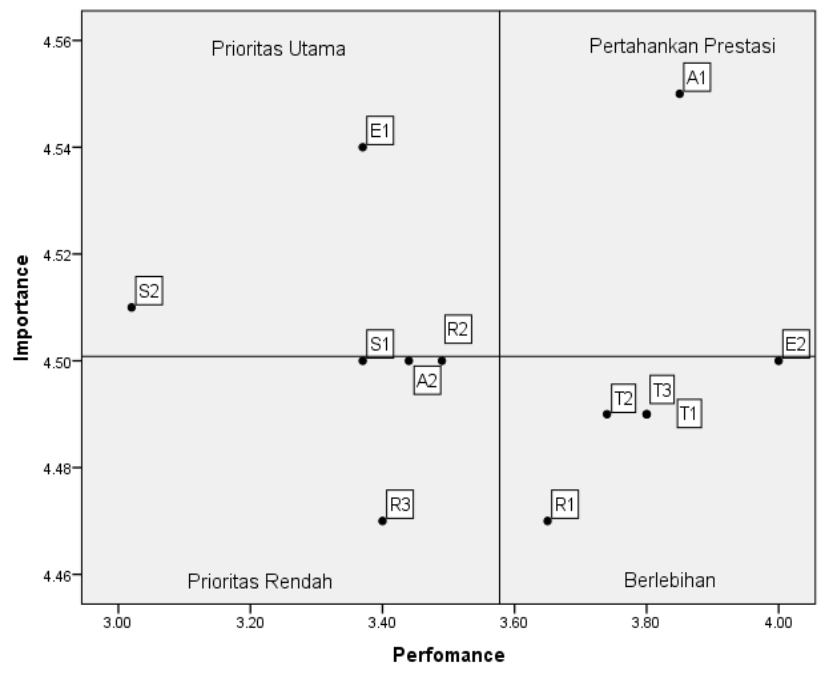

Gambar 1. Diagram IPA kepuasan anggota terhadap kualitas pelayanan KUD Mina Dermaga, 2020

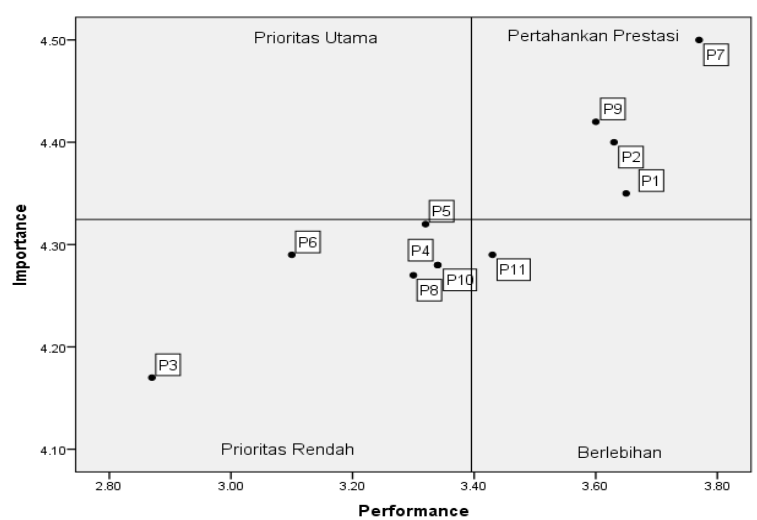

Gambar 2. Diagram IPA kepuasan anggota terhadap terpenuhinya kebutuhan anggota KUD Mina Dermaga, 2020

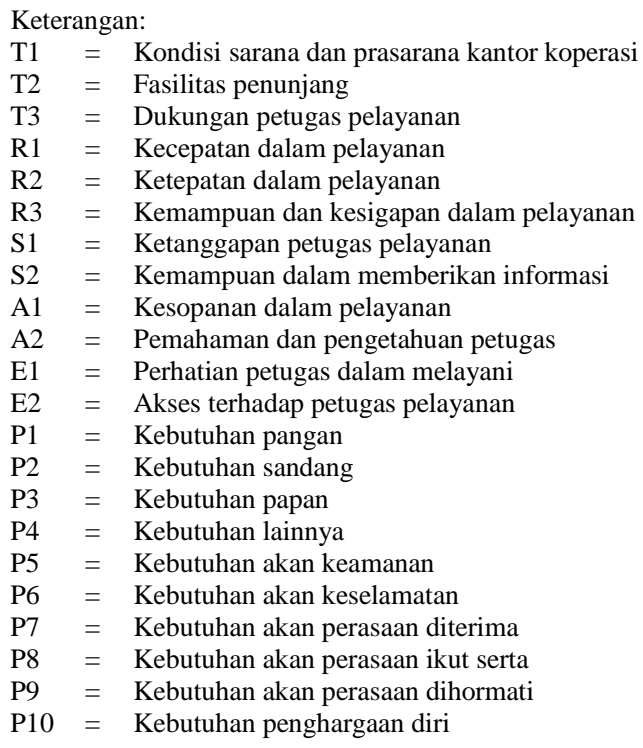

Hasil penelitian ini berbeda dengan hasil penelitian yang dilakukan oleh Sanjaya, Lestari, dan Situmorang (2017) penelitian tersebut mengukur kepuasan anggota dengan menggunakan metode metode Service Quality (ServQual) dan Importance Performance Analysis (IPA), yang menyebutkan bahwa aspek yang perlu diprioritaskan adalah sarana penunjang ruang kerja, penyelesaian proses pelayanan anggota, ketersediaan papan pengumuman, dan ketepatan informasi yang diberikan.

\section{KESIMPULAN}

Berdasarkan hasil penelitian dan pembahasan sebelumnya, dapat disimpulkan bahwa kinerja KUD Mina Dermaga sebagai badan usaha masuk dalam kategori berkualitas. 
Kinerja KUD Mina Dermaga yang berkaitan dengan pembangunan berada pada kategori berkualitas. Kinerja KUD Mina Dermaga terhadap kepentingan anggota masuk dalam kategori cukup berkualitas. Rata-rata manfaat ekonomi yang diterima anggota koperasi per tahun adalah Rp502.844,26. Manfaat nonekonomi berupa kepuasan yang diterima anggota koperasi masuk dalam kategori puas.

\section{DAFTAR PUSTAKA}

Dinas Koperasi dan UKM Provinsi Lampung. 2018. Rekapitulasi Data Koperasi Tingkat Provinsi. Dinas Koperasi dan UKM Provinsi Lampung. Lampung.

Hanel A. 2005. Organisasi Koperasi: PokokPokok Pikiran Mengenai Organisasi Koperasi dan Kebijaksanaan Pengembangan di Negara-Negara Berkembang. Graha Ilmu. Yogyakarta.

Hasibuan M. 2011. Manajemen: Dasar, Pengertian dan Masalah. Bumi Aksara. Jakarta.

Kementerian Negara Koperasi dan UKM RI. 2015. Pedoman Pemeringkatan Koperasi. Kementerian Koperasi dan Usaha Kecil dan Menengah Republik Indonesia. Jakarta.

Sanjaya HG, Lestari DAH, dan Situmorang S. 2017. Analisis keberhasilan Koperasi Amanah Kecamatan Langkapura Kota Bandar
Lampung. Jurnal Ilmu Ilmu Agribisnis, 5(1): 67-75.

https://jurnal.fp.unila.ac.id/index.php/JIA/issu e/view/155. [27 Maret 2020]

Saputri DN, Lestari DAH, dan Sayekti WD. 2019. Kinerja Koperasi Unit Desa (KUD) Mina Teluk Semaka di Kabupaten Tanggamus Provinsi Lampung berdasarkan Pendekatan Tripartite. Jurnal Ilmu Ilmu Agribisnis, 8 (3): 395-402.

https://jurnal.fp.unila.ac.id/index.php/JIA/artic le/view/1213/1110. [25 Maret 2020].

Sormin. 2019. Kinerjadan Strategi Pengembangan Koperasi Produksi Ternak (KPT) Maju Sejahtera Kecamatan Tanjung Sari Kabupaten Lampung Selatan. Skripsi. Jurusan Agribisnis. Fakultas Pertanian. Universitas Lampung. Lampung.

Sudarsono dan Edilius. 2005. Koperasi Dalam Teori dan Praktek. Renika Cipta. Jakarta.

Supranto J. 2006. Pengukuran Tingkat Kepuasan Pelanggan untuk Menaikkan Pangsa Pasar. Rineka Cipta. Jakarta.

Wiandhani N, Lestari DAH, dan Soelaiman A. 2015. Analisis manfaat koperasi dan partisipasi anggota Koperasi Perikanan ISM Mitra Karya Bahari di Kota Bandar Lampung. Jurnal Ilmu Ilmu Agribisni, 4(1): 40-47. http://jurnal/fp.

unila.ac.id/index.php/JIIA/article/view/1213/1 110. [5 Juli 2020]. 